Крихтіна Ю.О., к.е.н., доч., УДУЗТ, м. Харків, ORCID: 0000-0002-6595-4759

Krykhtina Y., PhD in Economic, Associate Professor of Management and Administration Department, Ukrainian State University of Railway Transport, Kharkiv

\title{
ПРОБЛЕМИ ТА СУПЕРЕЧНОСТІ ДЕРЖАВНОЇ ПОЛІТИКИ РОЗВИТКУ ТРАНСПОРТНОЇ ГАЛУЗІ УКРАЇНИ
}

\section{PROBLEMS AND CONTRADICTIONS OF STATE POLICY DEVELOPMENT OF THE TRANSPORT INDUSTRY OF UKRAINE}

Визначено проблеми та суперечності розвитку транспортної галузі Украӥни. Охарактеризовано сучасний стан розвитку видів транспорту транспортної галузі Украӥни. Підкреслено, що транспортна галузь України має великий потенџіал розвитку через вигідне розташування краӥни на перетині шляхів сполучення між західними та східними країнами. Зазначено, що транспортна галузь Украӥни потребує відповідної державної політики з метою підвищення ї̈ конкурентоспроможності. Визначено напрями формування та реалізаиії державної політики для вирімення існуючих проблем та суперечностей розвитку транспортної галузі України.

Ключові слова: державна політика, транспортна галузь, проблеми та суперечності розвитку транспортної галузі, підвищення конкурентоспроможності транспортної галузі.

Problems and contradictions of development of the transport branch of Ukraine are defined. The current state of development of transport modes of the transport industry of Ukraine is characterized. It is emphasized that the transport sector of Ukraine has a great potential for development due to the favorable location of the country at the intersection of roads between western and eastern countries. It is noted that the transport sector of Ukraine needs an appropriate state policy in order to increase its competitiveness. The directions of formation and realization of the state policy for the decision of existing problems and contradictions of development of transport branch of Ukraine are defined.

Keywords: state policy, transport sector, problems and contradictions of transport industry development, increasing competitiveness of transport sector.

Постановка проблеми. Транспортна галузь $є$ надзвичайно важливим сектором економіки України, яка значною мірою впливає на процеси подолання 
кризових явищ в країні, зміцнення обороноздатності держави, вирішення багатьох існуючих соціально-економічних та екологічних проблем. Українська транспортна система має розгалужену мережу транспортних шляхів, вигідне розташування країни на перетині шляхів сполучення між західними та східними країнами світу, а транспортно-дорожній комплекс $є$ одним 3 провідних у Європі за обсягами пасажирських і вантажних перевезень, перевезенням та оформленням транзитних вантажів, а також за наявністю магістральних газо- та нафтопроводів.

Аналіз останніх досліджень і публікацій. Дослідженням проблем та суперечностей державної політики розвитку транспортної галузі присвячено значну кількість наукових робіт таких вчених та практиків як Довгань В., Січкар Д., Танклевська Н., Чернявська Т., Черніхова О. та ін. [1; 5; 6; 7].

Однак чимало питань стосовно визначення напрямків формування та реалізації державної політики розвитку транспортної галузі для вирішення завдань $з$ підвищення іiі конкурентоспроможності залишаються недостатньо дослідженими.

Метою дослідження $є$ визначення напрямів формування та реалізації державної політики для вирішення існуючих проблем та суперечностей розвитку транспортної галузі України.

Виклад основного матеріалу. Слід зазначити, що за даними досліджень англійського інституту «Рендел», Україна посідає перше місце серед європейських країн за коефіціснтом транзитності [7].

Водночас існує багато проблем та перешкод, що стримують активний розвиток транспортної галузі, що вимагає від держави формування та реалізації відповідної політики іiі сталого розвитку в умовах існуючих викликів сьогодення.

Загальні проблеми та суперечності, що потребують розв'язання на державному рівні чітко визначені в Національній транспортній стратегії України на період до 2030 р., а саме:

- відсутність ефективної системи збору та обробки адміністративних даних в транспортній галузі, а отже об'єктивної оцінки іiі стану та перспектив розвитку;

- відсутність системного підходу до координації розвитку та довгострокового планування діяльності всіх видів транспорту з урахуванням соціальноекономічних потреб населення, бізнесу, оборони та геополітичних інтересів України;

- незавершеність адміністративної реформи, зокрема процесу розмежування функцій державного регулювання та контролю, включно 3 формуванням відповідних державних органів управління, операційної діяльності та функцій господарської діяльності транспортних підприємств;

- відсутність дієвих систем контролю за ефективністю прийняття управ- 
лінських рішень, недостатня прозорість звітності та провадження діяльності органів державної влади та суб'єктів господарювання державного сектору економіки в транспортній галузі;

- відсутність ефективної системи комунікацій та зворотних зв'язків між органами управління транспортом, транспортними підприємствами і користувачами транспортних послуг, що знижує ефективність управління транспортом та якість транспортно-логістичних послуг;

- відсутність системи критеріїв та показників оцінювання якості надання транспортних послуг;

- низький рівень розвитку інтермодальних, мультимодальних перевезень, транспортної логістики;

- тенденція до зниження ефективності використання пропускної спроможності;

- недостатній рівень конкуренції на ринку надання транспортних послуг та невідповідність європейським вимогам доступу до ринку транспортних послуг;

- недосконала тарифна політика у сфері надання транспортних послуг;

- низька швидкість доставки вантажів «від дверей до дверей» та у визначений строк;

- наявність «вузьких місць» транспортної інфраструктури;

- низька економічна привабливість використання судновласниками флоту під українським прапором;

- недосконала система запобігання та недопущення руйнування автомобільних доріг загального користування, зокрема габаритно-вагового контролю транспортних засобів та належного рівня відповідальності за перевищення дозволених параметрів, допустимих значень осьових навантажень транспортних засобів [3].

В цілому, транспортна система України представлена різними видами транспорту: залізничним, автомобільним, морським, авіаційним, тощо. Зважаючи на стратегічне значення транспортної галузі, охарактеризуємо технічноексплуатаційні можливості та розвиток кожного виду транспорту.

За довжиною мережі залізниць Україна посідає друге місце у Європі $(21,7$ тис. кілометрів залізниць), у Чорноморському, Азовському та Дунайському басейнах розташовано 18 морських торговельних портів; довжина внутрішніх водних шляхів на найбільших європейських річках Дунай та Дніпро - 2,2 тис. км [2].

Однак, залізничний транспорт має застарілі основні фонди: застарілий парк транспортних засобів та технічне оснащення колій. Необхідно зауважити, що останнім часом рухомий склад поступово оновлюється закупівлею та будівництвом як закордонних, так і вітчизняних вагонів та локомотивів, однак цього замало, адже технічний стан колій, вокзалів та станцій ще знахо88 
диться на низькому рівні. Проходження пасажирських та вантажних поїздів через кордон $є$ проблематичним, оскільки існує невідповідність ширини колій української залізниці та європейської, що значно сповільнює рух потягів.

Найбільш поширеним в Україні є автомобільний транспорт, однак його використання ускладнено цілою низкою проблем. Хоча, в останні роки в Україні активно будуються дороги, головною проблемою залишається поганий стан доріг, внаслідок застосування недосконалих технологій будівництва дорожнього покриття, корупційних проявів, відсутності відповідальності підрядчиків за стан побудованих доріг, а також відсутності відповідальності чиновників щодо використання бюджетних грошей на зазначене будівництво. Це призводить до того, що дороги, які побудовані, через рік використання вже потребують ремонту. До цього додається не правильне використання доріг через пересування перевантажених великовагових автомобілів дорогами загального призначення та жорсткі кліматичні умови нашої країни. А оскільки Україна $є$ транзитною країною, ця проблема є актуальною не лише для українських перевізників, а й для закордонних. Вирішенням існуючих проблем може стати, як капітальна реконструкція вже існуючих, так і будівництво нових доріг. Для цього важливо дотримуватися жорсткого контролю за технологією виробництва та ремонту дорожнього покриття, залучити закордонних інвесторів, а також забезпечити жорсткий контроль фінансування робіт.

Треба визнати, що масова автомобілізація населення стає альтернативою громадському транспорту, що створює новий стиль життя та забезпечує мобільність населення. Особливо актуальним це $\epsilon$ в сучасних умовах, коли в умовах пандемії коронавірусу та карантинних обмежень, рух громадського транспорту обмежується. Однак зростаючим темпам автомобілізації країни не відповідають кількість та стан доріг та дорожніх розв'язок, внаслідок чого держава несе фінансові, а, головне, людські втрати через низьку дорожньотранспортну безпеку. На жаль, безпека громадського транспорту теж недостатня через застарілий вид транспорту, що використовується [4].

Україна також має розгалужену річкову мережу та вихід до Чорного та Азовського морів, тому водний транспорт є досить перспективним, хоча й дещо занедбаним. Попит на перевезення вантажів та пасажирів водним транспортом перевищує пропозицію. Застарілий рухомий склад, причали та пристані, навантажувально-розвантажувальні засоби потребують модернізації. Погіршило ситуацію й те, що АР Крим було анексовано Росією в 2014 p.

Наявність морських портів $є$ запорукою економічного співтовариства 3 іншими країнами, тому перевезення морським транспортом для України має бути пріоритетним напрямом розвитку транспортної галузі [6].

Окремо слід охарактеризувати авіаційний транспорт України. Галузь авіаційного транспорту найбільше постраждала від карантину у зв'язку 3 
поширенням COVID-19, тому потребує системних заходів державної підтримки у відповідності з визначеними потребами аеропортів на основі оцінки поточної пропускної спроможності та стану об'єктів інфраструктури аеропорту, програм 3 вдосконалення та розширення, що знаходяться на етапі реалізації, та пропускної спроможності, необхідної для задоволення очікуваного попиту пасажирів.

Для підтримки українських аеропортів та авіакомпаній у зазначений кризовий період було прийнято зміни до Повітряного кодексу України щодо вдосконалення механізму справляння державних зборів за кожного пасажира, який відлітає з аеропорту України та за кожну тонну вантажу, що відправляється чи прибуває до аеропортів України. «Украерорух» залучив кредит на суму 25 млн. євро від СБРР для поповнення обігових коштів, на виплату фонду оплати праці, сплату обов'язкових платежів та фінансування критично важливих для провайдера аеронавігаційних послуг операційних витрат [1].

Необхідно також відмітити позитивні зрушення щодо розвитку міжнародних вантажних авіаперевезень. Вже розпочалося будівництво вантажного терміналу ДП МА «Бориспіль», для якого вже виділено додаткові земельні ділянки. Очікується, що протягом 2021-2023 рр. буде збудований новий вантажний термінал аеропорту «Бориспіль», після чого нинішній застарілий термінал буде реконструйовано та модернізовано, тобто планується створення нових можливостей для розвитку потенціалу аеропорту та створення великого транспортного хабу. Загальна площа нового вантажного терміналу складе

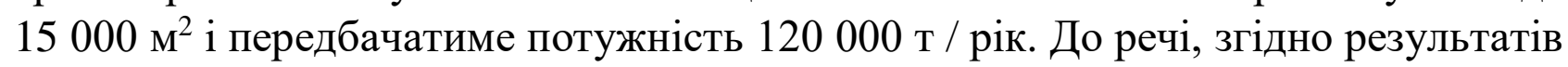
Інфраструктурного індексу, 83\% респондентів вважають, що необхідною реформою в контексті подальшого розвитку авіаційного транспорту України $\epsilon$ саме розвиток аеропорту «Бориспіль», як міжнародного хабу [5].

Зрозуміло, що подальший розвиток авіаційної галузі країни потребує значних інвестицій, в тому числі іноземних, що вимагає формування та реалізації відповідної державної політики.

Що стосується сервісного обслуговування клієнтів, то, на жаль, його рівень залишається низьким для всіх видів транспорту. Також спостерігається відставання в розвитку транспортної інфраструктури від країн Європи, транспортно-логістичних технологій, мультимодальних перевезень, рівня контейнеризації, що зумовлює високу частку транспортних витрат у собівартості продукції.

3 огляду на те, що транспортна галузь $є$ стратегічною, потребують розв'язання такі основні проблеми та суперечності, а також необхідно вирішити завдання:

- удосконалення системи збору, аналізу та використання статистичних даних;

- виконання програм зміцнення потенціалу органів виконавчої влади в 90 
транспортній галузі та продуктивності праці державних службовців (система підготовки персоналу) у зазначеній галузі;

- використання кращого світового досвіду для забезпечення розвитку транспортної галузі;

- забезпечення розвитку транспортної інфраструктури відповідно до стандартів $\mathrm{CC}$;

- підвищення відповідальності та прозорості під час прийняття управлінських рішень, в першу чергу, впровадження системи відкритих даних, електронних сервісів та інших заходів щодо запобігання та протидії корупції;

- впровадження електронного урядування з метою зниження навантаження і спрощення адміністративних процедур для бізнесу тощо;

- визначення системи показників реструктуризації державних компаній 3 метою комерціалізації, демонополізації і відкритої конкуренції, підвищення прозорості, боротьби з корупцією, зменшення транспортних витрат та збільшення ефективності транспорту, в тому числі, завершення структурної реформи ПАТ «Укрзалізниця», позбавлення невластивих функцій державного управління державного підприємства «Адміністрація морських портів України»;

- удосконалення управління державними активами в авіаційній інфраструктурі;

- підвищення ефективності внутрішніх логістичних операцій вантажного транспорту через усунення існуючих перешкод та вдосконалення відповідної інфраструктури, а також їі поєднання 3 міжнародною та Транс'європейською транспортною мережею (TEN-T);

- забезпечення комплексного вирішення питань, зокрема підготовка та реалізація відповідної концепції або виконання програми розвитку мультимодальних перевезень та логістичних технологій;

- забезпечення розвитку пріоритетної мережі автомобільних шляхів, в першу чергу введення європейських стандартів проектування, розроблення та обслуговування автомобільних доріг, підвищення рівня якості автодорожнього покриття та обгрунтованість вибору його типу, зокрема шляхом поступового відновлення експлуатаційних характеристик дорожньої мережі;

- впровадження довгострокових контрактів 3 експлуатаційного утримання автомобільних доріг на основі їх роботи та кінцевих результатів;

- створення конкурентного середовища та сприятливого бізнес-клімату на ринку надання транспортних послуг, зокрема розширення переліку послуг, що надаються підприємствами транспортної галузі;

- забезпечення створення рівних та прозорих умов (на ринку) надання транспортних послуг;

- забезпечення розвитку залізничного транспорту, в першу чергу лібералізація ринку залізничних перевезень на основі рівноправного доступу до залізничної інфраструктури та справедливої конкуренції між перевізниками; 
- поступова лібералізація міжнародних автомобільних вантажних перевезень;

- запровадження нового підходу до ліцензування автомобільних перевізників 3 передбаченням, зокрема, вимог щодо ділової репутації, фінансової спроможності, професійної компетентності персоналу та забезпечення процедури доступу до ринку автомобільних перевезень відповідно до законодавства $\epsilon \mathrm{C}$;

- забезпечення розвитку водного транспорту, зокрема, інституціональне та законодавче забезпечення виконання Україною своїх зобов'язань, як держави прапора, держави порту та прибережної держави відповідно до міжнародних договорів України і законодавства СС;

- забезпечення розвитку авіаційного транспорту та створення умов для сталого розвитку авіаційних перевезень, зокрема, лібералізація авіаційних перевезень, зокрема шляхом зняття обмежень на паритетних засадах щодо кількості призначених авіапідприємств, пунктів та частот під час виконання польотів між Україною та країнами світу і створення системи кібернетичної безпеки цивільної авіації з урахуванням стандартів та рекомендованої практики IКАО та законодавства $€ C$;

- впровадження прозорих та ефективних тарифних моделей, перехід до ринкової практики встановлення тарифів на перевезення:

- розроблення порядку формування тарифів відповідно до фактичної структури витрат, вимог стабільного розвитку, забезпечення вільного ціноутворення у конкурентних секторах ринку надання транспортних послуг;

- проведення реформи системи тарифоутворення на послуги залізничних перевезень;

- проведення реформи тарифного регулювання у сфері перевезення пасажирів автомобільним та міським електротранспортом відповідно до передового світового досвіду;

- розроблення та затвердження методики розрахунку ставок портових зборів, перегляд їх розміру з урахуванням структури та напрямків вантажопотоків, що забезпечить підвищення привабливості морських торговельних портів для користувачів транспортних послуг та створення гарантованого джерела компенсації витрат на відтворення та розвиток портової інфраструктури;

- перегляд політики формування річкових тарифів та зборів з метою стимулювання розвитку внутрішнього водного транспорту;

- підвищення конкуренції на ринку авіаційних перевезень, зокрема шляхом залучення нових, у т. ч. бюджетних авіакомпаній, та стимулювання наявних авіаперевізників, впровадження правил доступу до ринку наземного обслуговування відповідно до законодавства СС [3].

Вирішення зазначених проблем та суперечностей потребує відповідної державної стратегії їх розв'язання. Так, згідно з Національною транспортною 92 
стратегією України на період до 2030 р., передбачається зростання обсягів інвестицій у транспортну галузь, що забезпечить оновлення не менше ніж 90\% основних фондів, а збільшення обсягів приватних інвестицій в оновлення рухомого складу заплановано у розмірі 10,1 млрд. грн. на рік. Крім того, до 2030 р. планується досягти рівня локалізації виробництва інноваційного рухомого складу на українських підприємствах на рівні не менше ніж 80\%; збільшити кількість доріг загального користування державного значення з твердим покриттям, які відповідають нормативним вимогам, до 70\% загальної кількості; скоротити частину сільського населення, що проживає на відстані більше ніж 3 км від таких доріг, до $0,5 \%$ й охопити $90 \%$ сіл та селищ регулярним автобусним сполученням. Надзвичайно важливим $\epsilon$ те, що з метою охорони довкілля, до 2030 р. планується збільшити використання електротранспорту, підвищивши його кількість у внутрішньому сполученні до 75\%, а також збільшити обсяги застосування альтернативних видів палива та електроенергії [3].

Висновки. Таким чином, формування та реалізація державної політики розвитку транспортної галузі України в сучасних умовах має передбачати: підвищення ефективності та конкурентоспроможності галузі в умовах жорсткої міжнародної конкуренції; підвищення економічної ефективності всіх секторів та сфер транспортної галузі; забезпечення гарантованого доступу населення до послуг транспортної галузі шляхом підвищення його платоспроможності (необхідно створити умови, коли український споживач транспортних послуг стане основним інвестором транспортної галузі України, тобто перетворити внутрішній попит на основний ресурс розвитку цього сектору економіки).

Окрім того, стратегія розвитку транспортної галузі України в контексті формування та реалізації державної політики у сфері європейської інтеграції має полягати у системній та всесторонній адаптації цього сектору економіки до нових умов і викликів та підвищення ефективності використання наявного іiі потенціалу. Свроінтеграційні процеси є важливими для подальшого розвитку національної транспортної галузі, адже формуються нові можливості для ії сталого розвитку за умов підвищення якості транспортних послуг, їх безпечності, покращення екологічних характеристик діяльності зазначеної сфери економіки, що й буде предметом подальших наукових досліджень.

\section{Список використаних джерел:}

1. Довгань В. Перспективи розвитку авіаційної галузі України. URL: https://cfts.org.ua/.

2. Інформація Державного комітету статистики України. URL:http://www.ukrstat.gov.ua.

3. Про схвалення Національної транспортної стратегії України на період до 2030 року. URL: https://zakon.rada.gov.ua/laws/show/430-2018-\%D1\%80\#Text. 
4. Реалізація транспортного потенціалу транспортної інфраструктури України в стратегії посткризового економічного розвитку. Аналітична доповідь. К. : НІСД, 2011. 37 c.

5. Січкар Д. Транспортна галузь у 2020 році. URL: https://eba.com.ua/transportnagaluz-u-2020-rotsi.

6. Танклевська Н.С., Чернявська Т.А. Сучасні проблеми розвитку транспортного сектору України. Облік i фінанси АПК: освітній портал. URL: $\quad$ http://magazine.faaf.org.ua/suchasni-problemi-rozvitku-transportnogo-sektoruukraini.html.

7. Черніхова О. С. Проблеми та перспективи розвитку транспортної галузі України. URL: https://naukam.triada.in.ua/index.php/konferentsiji/50-dvadtsyatavseukrajinska-praktichno-piznavalna-internet-konferentsiya/461-problemi-ta-perspektivirozvitku-transportnoji-galuzi-ukrajini.

\section{References:}

1. Dovgan V. Prospects for the development of the aviation industry of Ukraine. [Perspektyvy rozvytku aviatsiynoyi haluzi Ukrayiny]. URL: https://cfts.org.ua/.

2. Information of the State Statistics Committee of Ukraine. [Informatsiya Derzhavnoho komitetu statystyky Ukrayiny]. URL: http: //www.ukrstat.gov.ua.

3. On approval of the National Transport Strategy of Ukraine for the period up to 2030. [Pro skhvalennya Natsional'noyi transportnoyi stratehiyi Ukrayiny na period do 2030 roku]. URL: https://zakon.rada.gov.ua/laws/show/430-2018-\%D1\%80\#Text.

4. Realization of the transport potential of the transport infrastructure of Ukraine in the strategy of post-crisis economic development. [Realizatsiya transportnoho potentsialu transportnoyi infrastruktury Ukrayiny $\mathrm{v}$ stratehiyi postkryzovoho ekonomichnoho rozvytku]. Analytical report. K. : NISS, 2011.37 p.

5. Sichkar D. Transport industry in 2020. [Transportna haluz' u 2020 rotsi]. URL: https://eba.com.ua/transportna-galuz-u-2020-rotsi.

6. Tanklevskaya N.S., Chernyavskaya T.A. Modern problems of development of the transport sector of Ukraine. [Suchasni problemy rozvytku transportnoho sektoru Ukrayiny]. Accounting and finance of agro-industrial complex: educational portal. URL: $\quad$ http://magazine.faaf.org.ua/suchasni-problemi-rozvitku-transportnogo-sektoriukraini.html.

7. Chernikhova O.S. Problems and prospects of development of the transport industry of Ukraine. [Problemy ta perspektyvy rozvytku transportnoyi haluzi Ukrayiny]. URL: https://naukam.triada.in.ua/index.php/konferentsiji/50-dvadtsyata-vseukrajinska-praktichnopiznavalna-internet-konferentsiya/461-problemi-ta-perspektivi-rozvitku-transportnojigaluzi-ukrajini. 